\title{
TITLE:
}

\section{A COLLECTION OF MARINE NEMATODES FROM JAPAN}

$\operatorname{AUTHOR}(\mathrm{S})$ :

Wieser, Wolfgang

\section{CITATION:}

Wieser, Wolfgang. A COLLECTION OF MARINE NEMATODES FROM JAPAN. PUBLICATIONS OF THE SETO MARINE BIOLOGICAL LABORATORY 1955, 4(2-3): 159-181

ISSUE DATE:

1955-05-30

URL:

http://hdl.handle.net/2433/174529

RIGHT: 


\title{
A COLLECTION OF MARINE NEMATODES FROM JAPAN ${ }^{1)}$
}

\author{
WOLFGANG WIESER \\ Zoological Institute, Lund, Sweden
}

With 10 Text-figures

Hitherto not more than 5 nematodes from Japanese waters have been known. SteIner \& Höppli (1926) described Acanthopharynx japonicus, Croconema mamillatum, Euchromadora archaica (= E. loricata) and Dicriconema tenuis from the shore of Joshi Island near Kobe, and in 1951 ALLGEN described Leptosomatum abyssale from the Sagami Sea in 400 fathoms depth.

On the East Asiatic mainland the situation is not much different since only one collection from Hoshiga Ura, near Port Arthur consisting of 6 species of nematodes is known (SteIner 1922). These 6 species are: Phanoderma macrophallum, Eurystoma terricola var. ophthalmophora (= Eurystomina ornatum), Cyatholaimus asiaticus (= Acanthonchus gracilis), Monoposthia chinensis, Draconema cephalatum, and Siphonolaimus tenuis. Thus one may conclude that the free-living marine nematodes of East Asia are almost unknown.

I am therefore much obliged to Dr. Takasi TokiokA of the Seto Marine Biological Laboratory for having sent to me a collection of nematodes which proved to contain 26 species, of which 21 could be determined. Of these, 4 species are new to science. Of the 11 species already known from East Asia, and mentioned above, only one, viz. Eurystomina ornatum, was present in the material. The locality in which the sample was collected is just below the Seto Marine Biological Laboratory, Shirahama-tyô, Wakayama-ken. This is far south of Osaka, on the western coast of Kii Peninsula near Siono-misaki, the southernmost cape of the peninsula.

The nematodes are derived from Sargassum spp. growing on the rocks below low water mark. The area is exposed to the open sea and the surface of the rocks is practically without sediments.

The following species were found:

Halalaimus sp.

2 \%

Enoplus sp. 1

9 juv.

Enoplus sp. 2

1 juv.

Syringolaimus striaticaudatus DE MAN

1 o, 1 우, 1 juv.

1) Contributions from the Seto Marine Biological Laboratory, No. 252.

Publ. Seto Mar. Biol. Lab., IV (2-3), 1955. (Article 15) 
Oncholaimus dujardini DE MAN

Viscosia carnleyensis (DITLEVSEN)

Eurystomina ornatum (EBERTH)

Polygastrophora tenuicollis (ALLGEN)

Paracanthonchus hawaiiensis AlLGEN

Acanthonchus setoi nov. spec.

Halichoanolaimus robustus (BASTIAN)

Desmodora scaldensis DE MAN

Chromadora macrolaimoides STEINER

Chromadora brevipapillata MicoletzKY

Chromadora nudicapitata BAsTIAN

Chromadorina inversa nov. spec.

Chromadorella filiformis (BASTIAN)

Euchromadora Tokiokai nov. spec.

Euchromadora amokurae (DITLEVSEN)

Neochromadora craspedota (STEINER)

Spilophorella tollenifera nov. spec.

Spilophorella paradoxa (DE MAN)

Chromadoropsis parva (DE MAN)

Linhomoeus sp.

Paramonhystera paranormandica (Micoletzky)

Monhystera sp.

Total of specimens
1 o, 1 i , 3 juv.

1 ơ, 3 古, 3 juv.

9 ๙, 2 우, 4 juv.

3 juv.

1 우, 1 juv.

1 o , 1 우

1 juv.

2 우, 2 juv.

2 ॐ, 1 우, 3 juv.

1 ㅇ․

20 ơ, 28 우, 7 juv.

1 \%.

3 ㄱ, 3 우

6 \% 5 \&, 6 juv.

1 juv.

1 이, 1 우

7 우, 7 우

1 우

3 ơ, 3 우

1 ?

1 우

10,2 우

167

\section{Taxonomic Notes}

The scale in the following figures represents, if not stated otherwise, $10 \mu$.

Family Ironidae

Syringolaimus striaticaudatus DE MAN 1888

Syn.: S. smarigdus Cовв.

10,1 o, 1 juv.

The species is cosmopolitan. Amongst other places it was found in great numbers around the Sunda Islands (Micol. \& KREIS 1930).

\section{Family Oncholaimidae}

\section{Oncholaimus dujardini DE MAN 1878}

1 o 1 ㅇ, 3 juv. For synonyms see Wieser 1953.

$$
\begin{array}{lrrrr}
\text { of : } & \mathrm{L}=2.67 & \mathrm{a}=53.5 & \mathrm{~b}=6.3 & \mathrm{c}=46.3 \\
\text { ㅇ : } & 2.88 & 50.0 & 6.8 & 35.8 \quad \mathrm{Vu}=73.4 \% \\
& \multicolumn{7}{c}{-2} &
\end{array}
$$


The specimens are typical save for the position of the excretory pore which lies nearer to the anterior end than hitherto described. In the female it is situated immediately behind the buccal cavity and in the male 1.4 stomatal lengths behind the anterior end (as against 2-2.4 stomatal lengths in my Chilean specimens). STEINER (1915) reported a specimen from Sumatra with the excretory pore at a distance of 3 stomatal lengths behind the anterior end. Thus it seems that the position of the excretory pore is subject to great variation; it cannot be used as a basis for specific or subspecific distinction in this species.

Cosmopolitan (Atlantic, Mediterranean, Black Sea, Pacific).

\section{Viscosia carnleyensis (DITLEVSEN 1921a)}

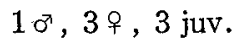

Cf. WIEsER 1953.

$$
\begin{array}{lrrrrr}
\sigma^{3}: \mathrm{L}=1.45 & \mathrm{a}=41.8 & \mathrm{~b}=5.5 & \mathrm{C}=7.5 & \\
\text { 우 : } & 1.53 & 36.4 & 5.3 & 7.3 & \mathrm{Vu}=47.5 \%
\end{array}
$$

The tail in the female measures 9 anal diameters.

Distribution: Auckland Islands, Sunda Islands, Chilean coast.

Family Enchelidiidae

Subfamily Eurystomininae

Eurystomina ornatum (EBERTH 1863)

(Fig. 1)

Syn. E. tenue MARION 1870

E. assimilis (DE MAN 1878)

E. filiformis DE MAN 1888

E. ophthalmophora STEINER 1922

It should be stressed again (cf. WIESER 1953, p. 136) that STEKHOvEN's criticism of the taxonomic treatment of this species by Micoletzky (1924a) is not justified. The relative length of the spicula varies not only individually, but also according to their position, that is to say, the spicula appear to be longer if they are withdrawn and the distal end covered by the heavily cuticularized accessory pieces. Moreover, EBERTh's figures are not exact enough to permit them to be taken as a basis of comparison in more subtle questions.

The present specimens make it clear beyond all doubt that STEINER's E. terricola var. ophthalmophora is also synonymous with $E$. ornatum (compare the present figure with those of STEINER 1922 and FilipJev 1918).

Thus the group B-2-b-aa in the key of my previous paper $(1953$, p. 136) contains only E. ornatum and E. ornatum var. indicum Micol. \& KREIS. However, the status of this latter species is doubtful too. It might be synonymous with E. eurylaima 
teeth at the distal end of the spicula which can be seen in FiLIPJEv's figures $29 \mathrm{c}$, d and in my present figure 1. Length of spicula 50-54 $\mu=40-50 \%$ of length of tail. Apophysis of accessory piece $31 \mu$ long. The dimensions of the two supplements and their distance from the anus can be taken from figure 1. As already mentioned the alae of the supplements were absent in one specimen.

Length of tail 2.6, anal diameters in male, 3.0 in female, and 3.5 in juveniles.

Distribution: Atlantic, Mediterranean, Black Sea, Arctic Sea, East Asia (Hoshiga Ura). Hawaii and California are doubtful (Allgen 1947, 1951).

\section{Subfamily Enchelidiinae}

Polygastrophora tenuicollis (ALLGEN 1951) aff.

(Fig. $2 \mathrm{a}-\mathrm{c}$ )

3 juv.

$$
\begin{array}{lrrrr}
\text { juv. 1: } & \mathrm{L}=0.88 & \mathrm{a}=23.0 & \mathrm{~b}=2.1 & \mathrm{c}=\text { ? } \\
\text { juv. 2: } & 1.14 & 43.8 & 3.0 & 11.0
\end{array}
$$

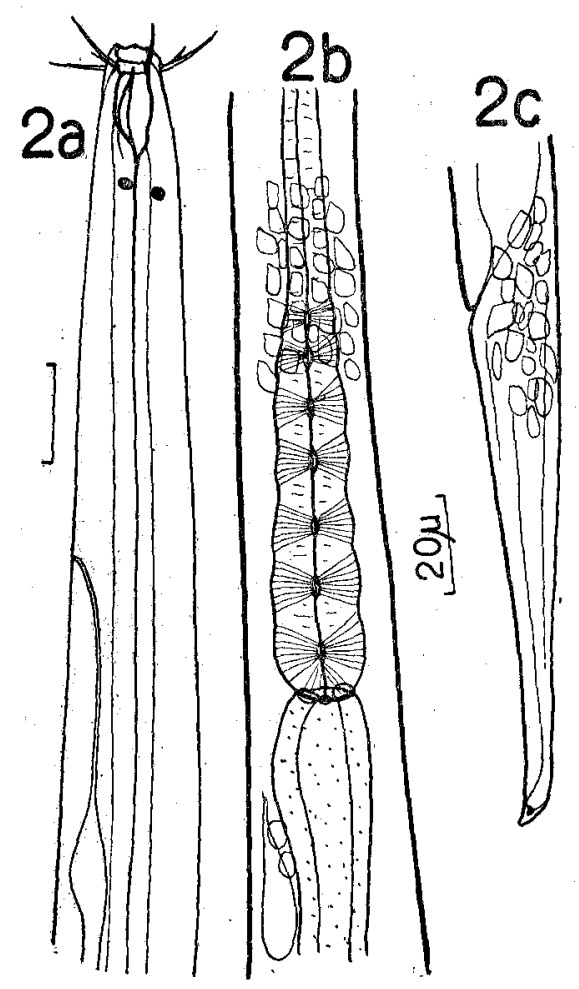

Fig. 2. Polygastrophora tenuicollis (ALLGEN).

a, Anterior end; $b$, region of pharyngeal bulb;

c, tail. All juveniles. 
Cephalic diameter $6.5 \mu$. Cephalic setae about 7.5 and $3.5 \mu$ long. Body diameter $6.5 \mu$. Cephalic setae about 7.5 and $3.5 \mu$ long. Body diameter at end of pharynx $32 \mu$. "Ocelli" $14 \mu$ behind anterior end. Buccal cavity $9 \mu$ long, typical shape with one acute dorsal tooth and several projections; two transverse rings in the anterior portion. Excretory pore in the smaller specimen $52 \mu$ behind anterior end, ampulla $77 \mu$. In the longer specimen the ampulla is $50 \mu$ behind the anterior end. That is to say, the distal portion of the excretory apparatus moves forwards with each moult, a phenomenon quite usual in this family. Pharynx with 7 bulbi. These bulbi were quite distinct in one specimen, less so in another. The intestine is weakly developed. Tail 5 anal diameters long.

Allgen's description is too inexact to establish beyond doubt the specific identity of his specimens and mine. Moreover, ALLGEN had only females and I only juveniles at hand. However, none of the important characters of the species contradicts Allgen's description save that in the latter no cephalic setae are mentioned or figured; but since in ALLGEN's last papers cephalic setae in general are only of sporadic occurrence this difference should not be taken too seriously.

The species has been reported from Hawaii.

\section{Family Cyatholaimidae \\ Subfamily Cyatholaiminae \\ Paracanthonchus hawaiiensis ALLGEN 1951}

1 ㅇ, 1 juv.

$$
\text { 우: } \mathrm{L}=1.20 \quad \mathrm{a}=24.2 \quad \mathrm{~b}=70 \quad \mathrm{c}=10.5 \quad \mathrm{Vu}=47.0 \%
$$

Head diameter $25 \mu$. Amphids $10.5 \mu$ wide, 4 turns. Ocelli $44 \mu$ behind anterior end. Tooth small. Cuticle homogeneous throughout. Excretory pore apparently in front of ocelli.

In general it is not possible to determine species of Paracanthonchus on the basis of females alone. However, this species I have only recently described from Chile (WIEser 1954) to which material the present specimens show such a striking resemblance that I think I am not mistaken in the classification. The most important characters are the ocelli, the absolutely homogeneous cuticle (as to the terms "homogeneous" and "heterogeneous" cuticle see WiesER 1953, p. 6), the very small tooth and the amphids with 4 turns. In all these respects the specimens from Chile and Japan completely agree.

Distribution: Hawaii, Chile.

\section{Acanthonchus CoBB 1920}

A comparison between the description of CoBb and of Ditlevsen (1921b) shows 
that the two genera Acanthonchus and Seuratiella are distinguished only by the presence or absence of a dorsal tooth. This is a character of no taxonomic value in the closely related genus Paracanthonchus (see WIESER 1954), for which reason it seems illogical to ascribe to it more than subgeneric importance in the present genus. Even that might be too much in the light of future knowledge and the two genera might prove to be synonymous. However, for the time being I maintain the subgeneric status for them. A key to the species reads as follows:

A) Tooth absent. 4 tubular supplements in male of which only the anterior is much bigger than the others.

Subg. Seuratiella (Ditlevsen 1921b)

(Note: ALLGEN claimed in 1933 that the type-and only--species of this subgenus, A. gracilis, is provided with a tooth. This opinion is contradicted not only by two different fairly clear descriptions of Ditlevsen $(1919,1921 \mathrm{~b})$, but also by a quite excellent description of STEINER, since there is no doubt that $A$. asiaticus (STEINER 1922) is synonymous with A. gracilis. In the light of these three independent investigations there is no possibility of defending AllgEn's view and we must presume the latter was dealing with another species.)

A. gracilis (DitLevSEN 1919)

Syn. Seuratia gracilis DiTL.

Seuratiella pellucida Ditlevsen 1921b

Cyatholaimus ampulaceus ALLGEN 1929

Cyatholaimus microdentatus ALLGEN 1929

Cyatholaimus asiaticus STEINER 1922

?Chromadora problematica DITLEVSEN 1919

B) Large tooth present. Subg. Acanthonchus CoBB s. str.

1) 4 tubular supplements in male of which the second anterior is larger than the 2 posterior ones, and the anteriormost twice as large as the second.

A. viviparus СовB 1920 (type)

Syn. Seuratiella pedroensis ALLGEN 1947

A. duplex (ALLGEN 1947) is either synonymous with the species above or distinguished by a distally more expanded accessory piece. The species is insufficiently described.

2) 5 preanal supplements of which only the anteriormost is much bigger than the others.

a) Amphids approximately one-third of the corresponding body diameter in width. The anterior supplement measures half the body diameter at its level. 3 very long postanal setae in male present.

A. cobbi Chitwood 1951

A. arcuatus (KreIs 1926): Syn. Paracanthonchus arcuatus, is either synonymous with $A$. cobbi or closely related to it. There are some structural differences in the male genital apparatus; the amphids seem to describe fewer turns and the postanal setae are not mentioned. 
b) Amphids in male measuring 65\% of the corresponding body diameter. Anteriormost supplement as long as the body diameter at its level. Postanal setae relatively short.

A. setoi n, sp.

A. californicus (AlLGEN 1947)

Syn. Seuratiella californicus, is a species inquirenda.

Acanthonchus (Acanthonchus) setoi n. sp.

(Fig. $3 \mathrm{a}, \mathrm{b}$ )

1 \% 1 우

$\sigma^{3}: \quad \mathrm{L}=1.22 \quad \mathrm{a}=36.0 \quad \mathrm{~b}=6.3 \quad \mathrm{c}=12.0$

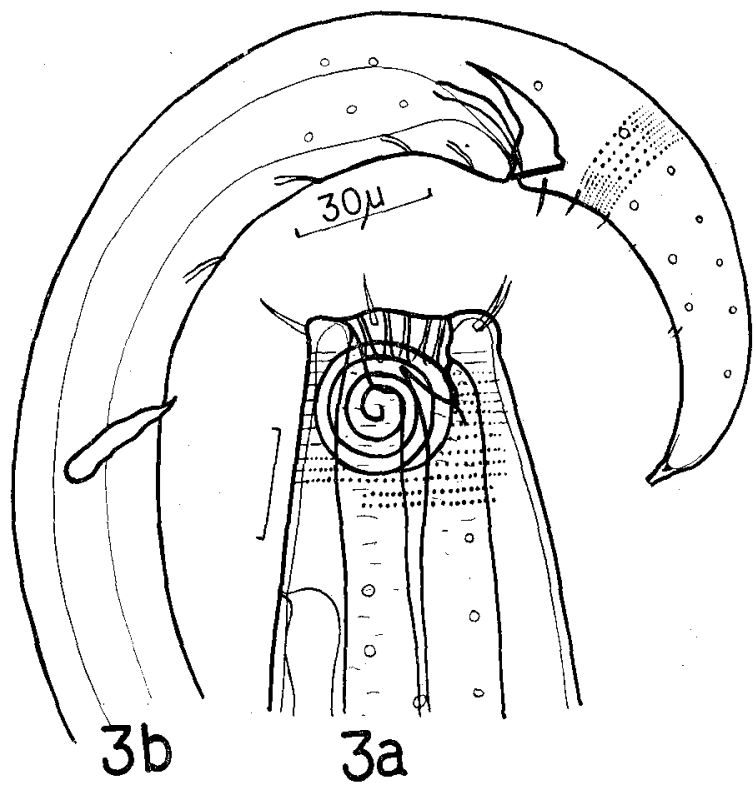

Fig. 3. Acanthonchus setoi n. sp.

a, Anterior end of male; $b$, posterior end of male.

Head diameter $17 \mu$. Cephalic setae measuring about one-third of the head diameter. Amphids very big in male, $12.2 \mu=65 \%$ of the corresponding diameter in width, describing somewhat more than 4 turns (it might be situated farther back than shown in fig. $3 \mathrm{a}$, since my single male was slightly curved in the slide). Excretory pore 1.3 head diameters behind anterior end. Buccal cavity very deep, armed with a big dorsal tooth. Cuticle homogenous in most parts of the body, heterogeneous on the tail. Pores numerous. Spicula length $26 \mu=0.8$ anal diameters, slightly cephalate proximally. Accessory piece double, $27 \mu$ long, distally $10.5 \mu$ wide and 
serrated. 5 preanal supplements present, the anteriormost of which measures $30 \mu$, that is about as much as the body diameter at its level. The distance between the anteriormost supplement and the anus is $120 \mu$.

Postanal setae present, not unusually long.

Male tail 3 anal diameters long.

The female was damaged and consequently no complementary data can be supplied.

\section{Subfamily Choanolaiminae \\ Halichoanolaimus robustus (BASTIAN 1865)}

1 juv. Apparently typical. Cephalic setae $4 \mu$ long, that is about one-eighth of the cephalic diameter. Amphids describing 3.5 turns, measuring one-fourth of the corresponding diameter in width.

Distribution: Baltic, North Sea (Kola Fjord, Murman), Mediterranean, Black Sea. According to Allgen (1948, 1951) also in California.

\section{Family Desmodoridae}

\section{Desmodora scaldensis DE MAN 1889}

(Fig. 4)

Syn. D. paramicrochaeta ALLGEN 1947

2 우, 2 juv.

$$
\begin{array}{lrrrrr}
\text { ㅇ 1 : } & \mathrm{L}=0.85 & \mathrm{a}=21.3 & \mathrm{~b}=6.6 & \mathrm{c}=10.1 & \mathrm{Vu}=57.1 \% \\
\text { ㅇ 2 } & 1.19 & 31.8 & 5.4 & 14.0 & \text { ? }
\end{array}
$$

My specimens are typical and prove what I presumed already in my treatment of the Chilean nematodes (1954) that $D$. paramicrochaeta ALLGEN is synonymous with $D$. scaldensis. Further, D. aucklandiae Dits. is very closely related, perhaps even synonymous, although in the absence of males this cannot be decided.

Head diameter $16 \mu$. Cephalic setae $7 \mu$ long. Amphids $7 \mu=37 \%$ of corresponding diameter in width. The tooth is slightly larger than figured by DE MAN. Tail 3.2 anal diameters long, conical.

Distribution: North Sea, Arctic (Relic Lake Mogihnoje, SavelJev 1912), Hawaii, California.

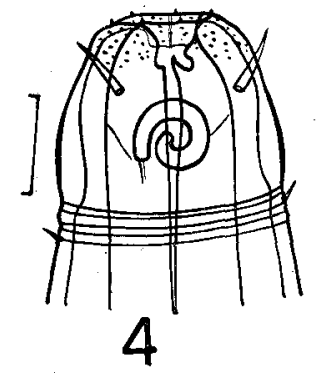

Fig. 4. Desmodora scaldensis DE MAN. Anterior end of female. 


\section{Family Chromadoridae \\ Chromadora BASTIAN}

The taxonomy of this genus is still unsettled. A large material from the Mediterranean which I had the opportunity to examine since I finished my monograph on the Chilean nematodes makes it clear that the key which I gave in this previous account (1954) has to be changed again in some important points. The taxonomic value of the micropapilla right in front of the male anus, and the shape of the pharyngeal bulb, have especially to be re-considered. It seems that the species $C$. nudicapitata is polymorphic and includes many more synonyms than hitherto assumed. The recognition of races will be possible in the future, but has to be based on a detailed quantitative study of the pertaining characters.

For this reason a new discussion of the genus would only be premature and I shall confine myself to a comparative representation of the three species found (Figs. 5-7).

However, I am able to establish one important distinction within the most difficult group 2 of my previous key. The species C. macrolaimoides and the closely related species $C$. brevipapillata are distinguished from all other species of this group by the following characters: Teeth very strong (compare figs. $5 \mathrm{a}$ and $6 \mathrm{a}$ with $7 \mathrm{a} !$ ); spinneret in females long, distal end ventrally bent; preanal papillae in males weak, not protruding and of a structure which differs slightly from that in other species; spicula with the proximal portion shorter than the distal one; accessory piece without the lateral plates (cf. CHITwOoD 1951 and my own figure of the male of C. brevipapilla$t a$ from the Mediterranean). These differences are very obvious for the experienced observer and allow even females to be separated. In the future it will perhaps be possible to establish a distinct subgenus for the species in question.

\section{Chromadora macrolaimoides STEINER 1915}

(Fig. $5 \mathrm{a}-\mathrm{c}$ )

For synonyms and discussion see WIESER 1954 . The slender tail is a valuable character in separating this species from the closely related C. brevipapillata, but not from the more distant species $C$. nudicapitata. In this case the length and shape of the spinneret and the shape of the teeth are of higher importance.

$2 o^{x}, 1$ \& 3 juv.

CHITwoon's recent description (1951) and my accompanying figures $5 \mathrm{a}-\mathrm{c}$ should suffice to recognice this species. However, my specimens differ from CHITwoon's and STEINER's in that they have longer cephalic setae. These measure $11 \mu$ in the female with a head diameter of $12.5 \%$. The taxonomic value of this difference cannot yet be decided. 
The teeth are very stout, especially the dorsal one. The bulb is oval, sometimes it is double, sometimes not. Tail in female 5.8 anal diameters long, in males 5.2. Spinneret $10 \mu$ long, distally bent. The spicula are exactly as CHITwood figures them; the ventral projection in their proximal portion is especially noteworthy. The accessory piece is enlarged distally as in the other species of Chromadora (this is figured by Steiner but not by Critwood), but they lack the lateral plates. Two weak preanal supplements are present in the position as figured by STEINER and CHITwood. Once more I want to stress that both spicula and supplements are of a shape different from that of other species of Chromadora (except C. brevipapillata).

Distribution: Mediterranean, Sumatra, British West Indies (Lesser Antilles), Gulf of Mexico.

\section{Chromadora brevipapillata MiCOLETZKY}

(Fig. $6 \mathrm{a}-\mathrm{c}$ )

1 우

$$
\text { ㅇ }: \quad \mathrm{L}=0.76 \quad \mathrm{a}=21.8 \quad \mathrm{~b}=5.6 \quad \mathrm{c}=7.6 \quad \mathrm{Vu}=50.0 \%
$$

Of this species $I$ have found both males and females in the collection of nematodes from the Mediterranean mentioned earlier. Since I shall give a detailed description, especially of the male, in a later publication the following short notes and the accompanying figures may suffice here. The species belongs to the same group as $C$. macrolaimoides, but is distinguished from the latter by the shorter cephalic setae (according to my own material), the shorter and plumper tail, and the more roundish pharyngeal bulb. Head diameter $13.5 \mu$. Cephalic setae $9 \mu$ long. Bulb roundish. Amphids loop-shaped (as in other species of Chromadora). Tail 4 anal diameters long. Spinneret measuring $9 \mu$, ventrally bent. Other characters as in C. macrolaimoides.

Known from the Mediterranean.

\section{Chromadora nudicapitata BASTIAN 1865}

(Fig. 7 a-d)

Syn. C. natans BASTIAN

C. quadrilinea FILIPJEV

C. trilinea PaRAmonow

C. quadrilineoides CHITwOOD

Other synonyms are possible.

$20 \sigma^{7}, 28$ क 7 juv.

It is unnecessary to give a detailed description of this well known species. All the important data can be inferred from the figures. The shape of the pharyngeal bulb varies somewhat. The tail is slender and provided with a short spinneret (especially in females). The teeth are more slender and smaller than in the two foregoing species. 


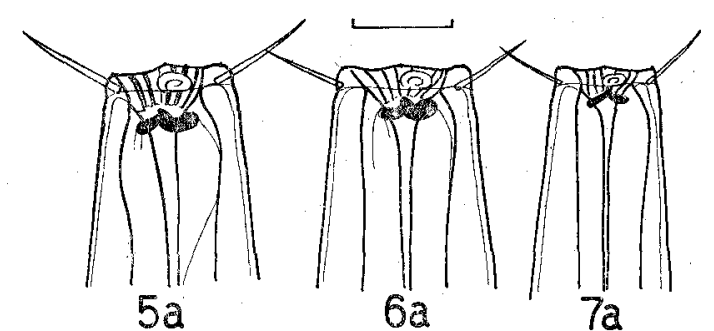

$5 a$

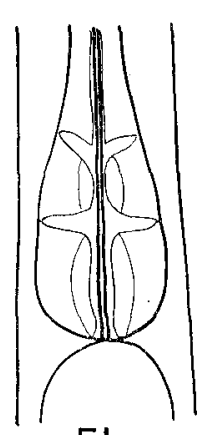

$5 b$

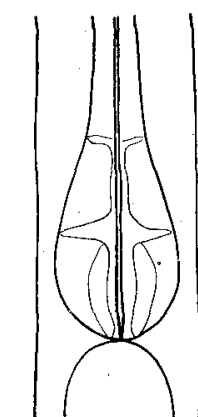

$6 b$

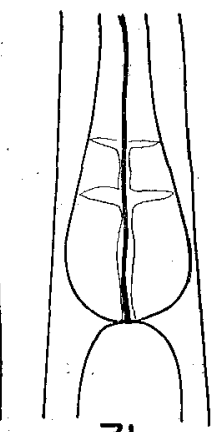

$7 b$

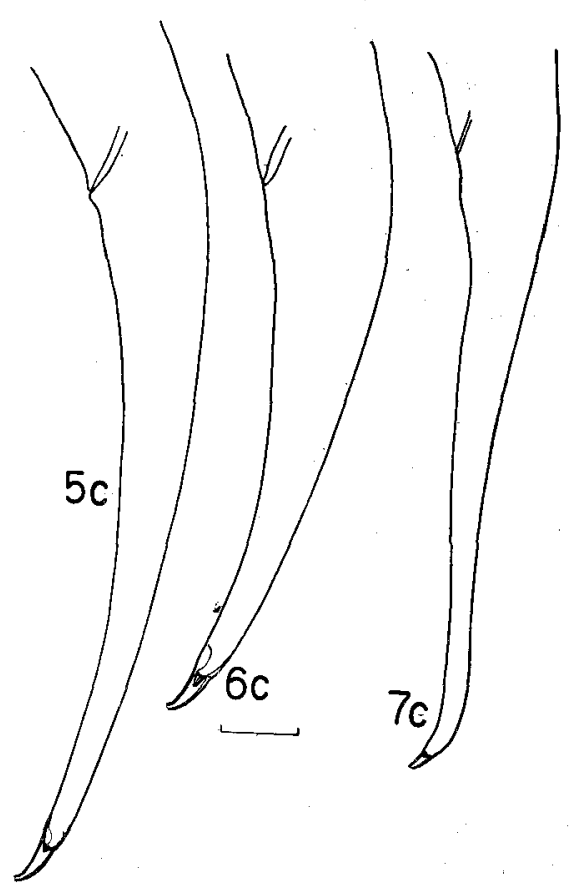

Fig. 5c. Chromadora macrolaimoides STEINER.

Fig. 6c. Chromadorabrevipapillata MicoleTzKY.

Fig. 7c. Chromadora nudicapitata BASTIAN. All tail of female.

Fig. 5. Chromadora macrolaimoides Steiner. a, Anterior end; b, pharyngeal bulb.

Fig. 6. Chromadora brevipapillata MiCOLETZKY. a, Anterior end; b, pharyngeal bulb.

Fig. 7. Chromadora nudicapitata BAsTIAN. a, Anterior end; b, pharyngeal bulb.

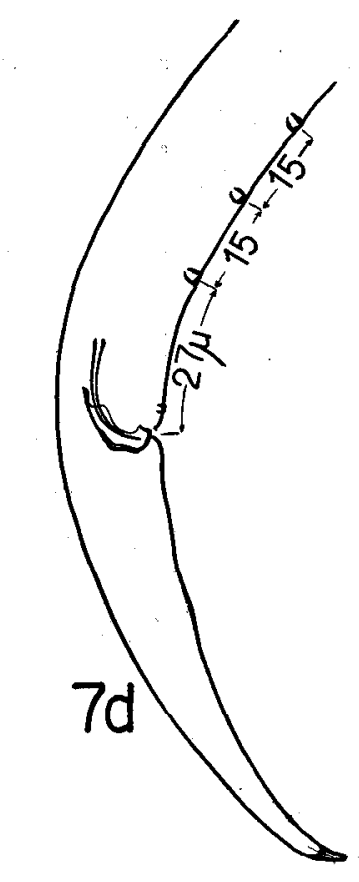

Fig. 7d. Chromadora nudicapitata BASTIAN. Tail of male. 
All the males were equipped with three large papillae and one micropapilla immediately in front of the anus. Studies on Mediterranean chromadorids have convinced me that the absence or presence of this micropapilla is due to individual variation; at least in the Mediterranean material, which was derived from one single locality (Piraeus, Greece), the micropapilla was present or absent in specimens which certainly have to be referred to one single species. The Japanese population, on the contrary, is very homogeneous and the micropapilla is present in all males. How this different behaviour of the two populations can be explained I do not know. The recognition of races is quite possible. On the other hand, the distribution of papillae characteristic of the Japanese population, i.e. $3+1$, was also met with in Greece, though very rarely. It is impossible to establish a race or subspecies on the distribution of papillae in one population if this same pattern of distribution occurs in a second population mixed with other patterns (as $4+1$, or 5 , or 6 ).

Typical for the present species is a postanal papilla in the middle of the male tail and a second one near the end of the tail. Both these papillae, particularly the latter, can be very inconspicuous and have, I am sure, been overlooked many times. In fact, as far as I can see, the distal papilla was never described before.

Distribution: One of the most widely distributed species of marine nematodes. It was found wherever nematodes were collected from seaweeds.

\section{Chromadorina inversa n. sp.}

1 우

$$
\text { 우: } \mathrm{L}=0.49 \quad \mathrm{a}=20.0 \quad \mathrm{~b}=5.3 \quad \mathrm{c}=4.7 \quad \mathrm{Vu}=\text { ? }
$$

Head diameter $10.5 \mu$. Cephalic setae $5.5 \mu$ long. Bulb roundish. Tail slender, 7 anal diameters long.

My single specimen agrees fully with material I have found in the Mediterranean, and of which I shall give a detailed description later on.

Distribution: Mediterranean.

\section{Chromadorella filiformis (BASTIAN 1865)}

Syn. Dichromadora tenuicauda STEKHOVEN 1950

? Chromadorella filiformoides CHITwood 1951

3 ơ, 1 우

$$
\begin{array}{lrrrr}
\sigma: & \mathrm{L}=1.23 & \mathrm{a}=35.6 & \mathrm{~b}=9.1 & \mathrm{c}=8.0 \\
\text { ㅇ } & 1.08 & 23.5 & 7.1 & 7.9 \quad \mathrm{Vu}=49.8 \%
\end{array}
$$

Since I possess à large collection of the closely related C. membranata Micol. from the Mediterranean I can now state with certainty that $C$. filiformis and the latter species are well distinguished. $C$. membranata possesses a lateral membrane, $C$. 
filiformis does not. In C. membranata the lateral rows of dots in the cervical region are one-twelfth of the corresponding diameter apart, in C. filiformis one-eighth.

CHITwood mentions as the only distinguishing character between C. filiformis and his $C$. filiformoides the absence of ocelli in the latter. I do not know whether this suffices to keep the two species separate since in chromadorids the ocellar pigment is easily resolved by preserving fluids.

Head diameter $17 \mu$. Cephalic setae $9 \mu$ long. Distance of lateral rows of dots from each other: $2.5 \mu$ in the cervical region (one-eighth of corresponding body diameter), $3.8 \mu$ in the mid-body (one-tenth), $3.5 \mu$ in the anal region (one-seventh).

Spicula $25 \mu$ long. Tail 5.6 anal diameters long. 5 supplements in the typical arrangement.

Distribution: North Sea, Atlantic, Mediterranean, Sargasso Sea, Sumatra, Australia, Hawaii, California; Gulf of Mexico?

\section{Euchromadora DE MAN}

In my previous treatment of this genus (WIESER 1954) I distinguished between two main groups of species, viz. one with powerful, the other with weakly developed buccal armature. Within the first group a further distinction can be made in species with an oval, well-defined bulb, and those in which the pharynx is gradually enlarging without forming a true bulb. This was also independently recognized by BRUNETTI (1951). The new species described below belongs to the group with gradually enlar ging pharynx and symmetrical spicula. Three species were hitherto known which are not easily separated due to our incomplete knowledge of E. africana. Without males determination is as yet impossible. The two old species $E$. striata and $E$. africana form one group in which the accessory pieces are half as long as the spicula. The new species, E. Tokiokai, and E. permutabilis WIESER 1954 belong to a second group in which the accessory pieces are two-thirds as long as the spicula. The differences between the four species in question are set out in the following table:

\begin{tabular}{|l|c|c|c|c|}
\hline & striata & africana & permutabilis & Tokiokai \\
\hline $\begin{array}{l}\text { Accessory pieces in } \\
\% \text { of spicula }\end{array}$ & 50 & & \multicolumn{2}{|c|}{66} \\
\hline Length of spicula & $70-90 \mu$ & $44-48 \mu$ & $104-133 \mu$ & $41-50 \mu$ \\
\hline $\begin{array}{l}\text { Length of female tail } \\
\text { in anal diameters }\end{array}$ & $5-6$ & $7.5-9$ & $3.5-4$ & $4.3-5.6$ \\
\hline $\begin{array}{r}\text { Length of female } \\
(\mathrm{mm})\end{array}$ & $1.6-2.1$ & $1.6-2.2$ & $2.0-3.1$ & $1.0-1.7$ \\
\hline
\end{tabular}

I should like to emphasize that it is indispensable for exact classification of species of Euchromadora to give measurements in $\mu$ of the male genital apparatus. 


\section{Euchromadora Tokiokai $\mathrm{n}$. sp.}

(Fig. $8 \mathrm{a}-\mathrm{c}$ )

6 ơ, 5 \& , 6 juv.

$$
\begin{array}{lrrrr}
\sigma^{7}: & \mathrm{L}=0.95-1.55 & \mathrm{a}=22.0-28.3 & \mathrm{~b}=5.1-6.0 & \mathrm{c}=7.0-9.0 \\
\text { \% : } & 1.03-1.69 & 20.0-24.5 & 5.0-5.5 & 7.6-8.8 \quad \mathrm{Vu}=50.0-52.3 \%
\end{array}
$$

(It is possible that in the above measurements last larval stages are also included-especially so in the males).

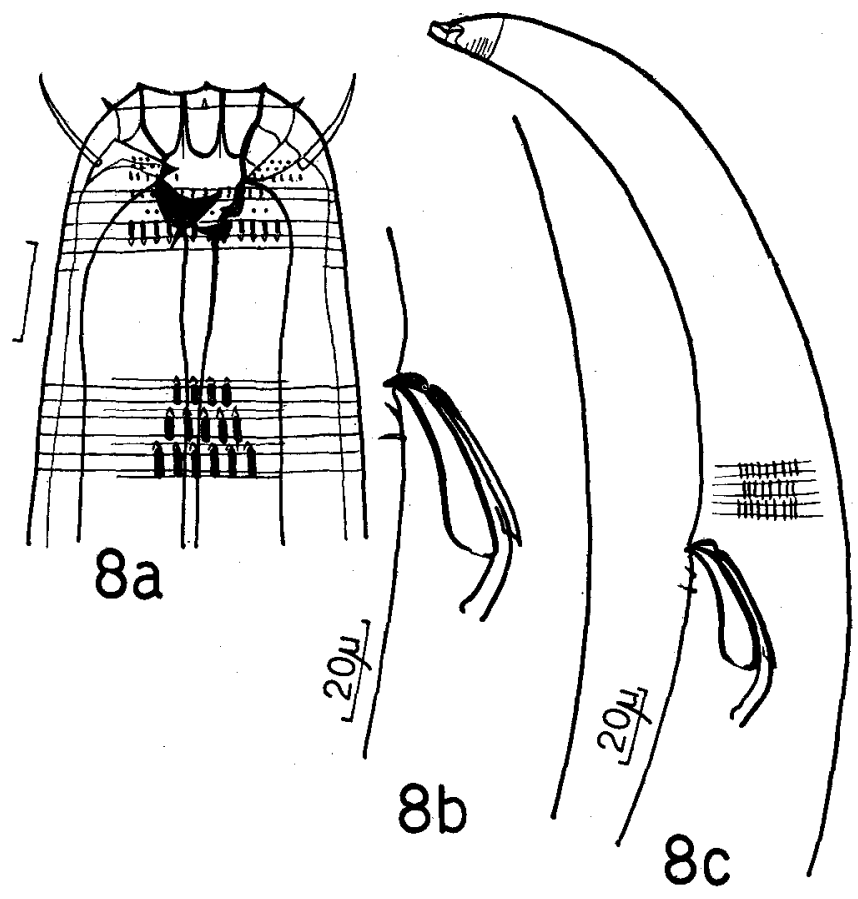

Fig. 8. Euchromadora Tokiokai n. sp.

$a$, Head of male; b, male genital apparatus

c, posterior region of male.

Head diameter 25-26 $\mu$. Cephalic setae $10-11 \mu$ long. Body diameter at end of pharynx $37 \mu .6$ labial papillae and 6 setose cephalic papillae present. Buccal armature and cuticle without special features. The latter is not differentiated laterally, not even in the anal region of the male.

Spicula $41-50 \mu$ long, without velum; proximal end with a slight ventral projection. Gubernacle $30-35 \mu$ long, lateral pieces dilated proximally and truncate. There are the usual two preanal setae. Tail in male $4.3-4.5$ anal diameters long, in female 4.3-5.6. 


\section{'Euchromadora amokurae (DITLEVSEN 1921a)}

Cf. WIESER 1954

1 juv. Typical specimen. This is a species widely distributed in the Pacific area.

Neochromadora craspedota (STEINER 1916)

(Fig. 9 a-e)

$10^{7}, 1$ \%

$$
\begin{array}{lrrrr}
\sigma^{7}: & \mathrm{L}=0.72 & \mathrm{a}=28.0 & \mathrm{~b}=6.5 & \mathrm{c}=7.7 \\
\text { ९ } & 0.80 & 21.4 & 7.2 & 7.2 \quad \mathrm{Vu}=44,7 \%
\end{array}
$$

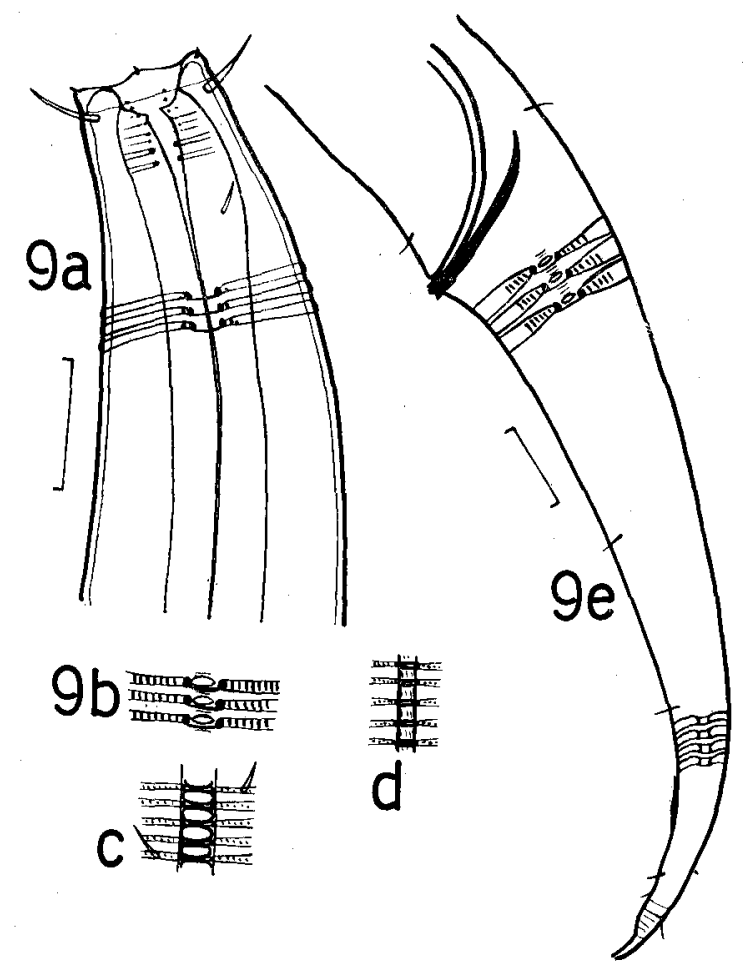

Fig. 9. Neochromadora craspedota (STEINER). a, Anterior end of male; b, lateral cuticular structure in pharyngeal region; $c$, in mid-body; $d$, posterior to mid-body; e, posterior region of male.

I am convinced that I have refound STEINER's species although the spicular apparatus seems to be bigger than figured in the original description. The lateral membrane consisting of quadrangular plates, seems to be a good characteristic and is of exactly the same shape in my specimens as described by STEINER. There are 
clearly two small hollow teeth present, the dorsal one being bigger than the subventral one. Their presence was only suspected by STEINER. Cephalic diameter $10.5 \mu$. Diameter at end of pharynx $24 \mu$. Cephalic setae $5.5 \mu$ long. There are 6 setose cephalic papillae. The cuticle consists of the usual bands with rod- or dot-like structures. Laterally they are interrupted by two longitudinal rows which are approximately $5 \mu$ apart. In the head region several rows of dots can be observed; then follows a region in which the transverse bands seem to be devoid of any secondary structures save the two lateral dots. At the end of the first third of the pharynx more and more rods make their appearance on the bands (figs. $9 \mathrm{a}, \mathrm{b}$ ). At the level of the bulb the first traces of the lateral membrane can be seen between the two lateral rows. In the mid-body and further behind, the rods on the bands have changed into dots. The membrane is conspicuous and consists of quadrangular plates. This feature is best to be seen posterior to the middle of the body (fig. $9 \mathrm{~d}$ ). In the anal region the membrane gradually disappears. There the bands are covered again with rod-like markings. All along the middle part of the body the lateral fields are accompanied by two sublateral rows of setae (fig. $9 \mathrm{c}$ ).

The spicula are $29 \mu=1$ anal diameter in length. The gubernacle measures approximately two-thirds of the length of the latter. It is cephalate distally, paired, and equipped there with two slightly outward-pointing teeth on each side.

The tail is 4 anal diameters long in the male, 6.5 in the female. Spinneret $9 \mu$ long.

Distribution: Öresound and North Sea, Arctic (Barents Sea), Campbell Islands. (Note: With the exception of the type specimens, all further findings were reported by ALLGEN who never described or figured the species again. Considering the doubtful status of the species this is regrettable since we cannot be sure whether ALLGEN really was dealing with STEINER's form).

\section{Spilophorella tollenifera n. sp.}

(Fig. $10 \mathrm{a}-\mathrm{c}$ )

$7 \sigma^{\top}, 7 q$

$\begin{array}{lrrrrr}\text { or 1: } & \mathrm{L}=0.66 & \mathrm{a}=21.6 & \mathrm{~b}=5.4 & \mathrm{c}=6.6 \\ \text { 이 2: } & 0.75 & 21.7 & 6.1 & 7.8 & \\ \text { 우 1: } & 0.73 & 19.0 & 5.7 & 7.6 & \mathrm{Vu}=50.0 \% \\ \text { 우 2: } & 0.73 & 16.0 & 5.6 & 7.6 & 50.0 \%\end{array}$

Head diameter $14-15 \mu$. Diameter at end of pharynx $27 \mu$. Cephalic setae $8.5 \mu$ long in male, $7 \mu$ in female. Buccal cavity deep and large, with especially well developed diadema. Dorsal tooth powerful, with two sublateral, backward-pointing apophyses which end posteriorly in two knobs or pivots under the cuticle. The apophyses are $15 \mu$ long. A casual observer would only see the two posterior knobs, since they are refractive just as the "ocelli" in Symplocostoma or Polygastrophora, 
and thus would consider them as "ocelli" too. A close examination, however, reveals their real nature which is purely mechanical.

The anterior end of the species seems to be slightly asymmetrical. In none of my specimens did I find the two longitudinal rows of cuticular dots in the lateral position which they assume in all other species of chromadorids. This might be due to the excessive development of the buccal armature. Opposite the dorsal tooth only a cuticularized pit in the buccal wall can be seen.

There are no cervical setae as in other species of this genus. The cuticle is typical for the genus. The longitudinal rows of dots have a distance from each other of $5 \mu$ in the anterior region ( $=$ onefourth to one-sixth of the corresponding body diameter), $4 \mu$ in the mid-body (one-eighth), and $3.5 \mu$ in the anal region (one-sixth). The transverse bands are smooth in the anterior cervical region, becoming covered with more and more rod-like markings posteriorly. These rods change to dots in the mid-body, so that each band carries two rows of tiny dots (fig. $10 \mathrm{c}$ ). In the mid-body region traces of a lateral membrane can be seen. The pharyngeal bulb is double but not very well developed. It measures $34-39 \times 22-26 \mu$. The spicula are $29-31 \mu$ long, regularly curved, with slight projections at the proximal end. The gubernacle is simple and about half as long as the spicula. It carries no teeth or projections as is usual in other species of this genus.

The tail is 5 anal diameters long in both sexes. Spinneret $9 \mu$ long, provided with one or two setae.

This species is distinguished from all other

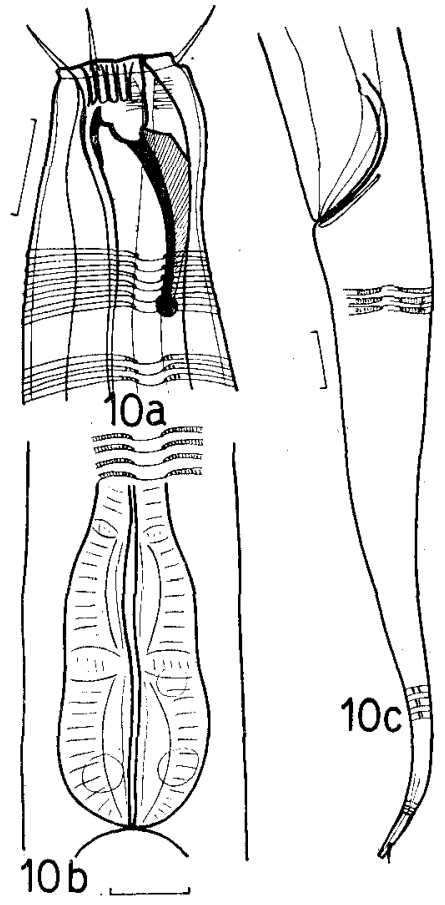

Fig. 10. Spilophorella tollenifera n. sp. a, Anterior end of male ; $\mathrm{b}$, pharyngeal bulb; $\mathrm{c}$, posterior end of male. species of Spilophorella by so many characters that it would be advisable in the future to reckon it to a distinct subgenus. These distinguishing characters are: The posterior apophyses of the dorsal tooth, the absence of cervical setae, the traces of a membrane in the mid-body, the simple structure of the male genital apparatus.

\section{Spilophorella paradoxa (DE MAN 1888)}

For synonyms and details see WIESER 1954.

1 typical female. The species is cosmopolitan. It is common on all European coasts and was also met with on both sides of the Pacific. 


\section{Chromadoropsis parva (DE MAN 1893)}

Syn. Spilophora, Chromadora, Chromadorina parva auctores Spilophora antarctica COBB 1914

3 ㅇ, 3 우

$$
\text { 우: } \mathrm{L}=0.67 \quad \mathrm{a}=24.7 \quad \mathrm{~b}=7.2 \quad \mathrm{c}=5.6 \quad \mathrm{Vu}=45.0 \%
$$

The specimens are typical. The spiral amphids are relatively easy to observe. The tail of a female measures 8 anal diameters. The spinneret is $9 \mu$ long.

The species is known from the North Sea, Mediterranean, Red Sea, Campbell Islands, Antarctic, and Chilean coast.

\section{Family Monhysteridae}

Paramonhystera (Leptogastrella) paranormandica (MicoletzKY 1922) aff. 19

Since I have only one female at my disposal an exact determination is difficult to obtain. In this subgenus the pilosity of the head is subject to some variation (cf. WIESER 1955). My single specimen shows apparently 12 cephalic setae, that is, less than Mrcoletzky (1924 b) describes. However, I found a similar variation in the closely related $P$. pellucida from the Chilean coast. The latter species and $P$. paranormandica are difficult to separate. The greater and more conspicuous amphids (60\% of corresponding body diameter as against less than 50\%) and the relatively longer tail of my specimen speak for $P$. paranormandica. However, without males it is impossible to decide whether one has not met with a new species.

$$
\text { ㅇ }: \quad L=1.20 \quad a=18.5 \quad b=5.0 \quad c=7.9 \quad \mathrm{Vu}=68.4 \%
$$

Head diameter $22 \mu$. Cephalic setae $10.5 \mu$ long. Longest cervical setae $10.5 \mu$ long. Longest cervical setae at least $20-22 \mu$ long, that is about one body diameter. Amphids approximately $12 \mu$ wide. Tail 4.5 anal diameters long.

The species was hitherto known from the Mediterranean only.

\section{Concluding Remarks}

The nematode fauna of this sample is typical for seaweeds without much detritus. Most of the well known genera from such habitats are represented, such as Enoplus, Oncholaimus, Viscosia, and--above all-the Chromadoridae. This family, which is so characteristic for exposed algae, makes up two-thirds of the total population. On the other hand, the family most typical for habitats rich in detritus, i.e. the Monhysteridae, is only sparsely represented. Chromadora nudicapitata, so often the most common species in similar habitats of sea coasts all over the world is also the most abundant species in the Japanese sample. 
One of the few genera which usually occur in such habitats but are lacking in this sample is Anticoma.

As to the geographical composition of the sample only very little can be said owing to the scarcity of our knowledge of the distribution of most species of marine nematodes. Anyhow, based on this limited knowledge the following groups of species can be distinguished:

1) Pacific species. Here belong the new species with exception of Chromadorina inversa which I know already from the Mediterranean, then Viscosia carnleyensis, Polygastrophora tenuicollis, Paracanthonchus hawaiiensis and Euchromadora amokurae. Of the latter four all but Polygastrophora tenuicollis are known from both sides of the Pacific.

2) Species from the Indo-West-Pacific and the Mediterranean.

To this group belong only three species: Chromadora brevipapillata, Chromadorina inversa and Paramonhystera paranormandica. It should be added that the determination of the last species is not quite reliable since only one female was present. These species occur neither on the east side of the Pacific nor in the Atlantic and Arctic.

3) Species from North Atlantic-Arctic and the Pacific.

Only Desmodora scaldensis and Neochromadora craspedota. The former species occurs also on the east side of the Pacific, the latter-according to ALLGEN-at the Campbell Islands (a cold-temperate area).

4) Species with a more or less cosmopolitan distribution.

This group comprises species which are known from the Atlantic, Mediterranean and both sides of the Pacific. They are: Syringolaimus striaticaudatus, Oncholaimus dujardini, Eurystomina ornatum (findings from the Pacific coast of America not quite reliable), Halichoanolaimus robustus, Chromadora nudicapitata, Chromadorella filiformis, Spilophorella paradoxa and Chromadoropsis parva. Chromadora macrolaimoides forms a transition between this latter group and group 2 since it is known from the IndoWest-Pacific, the Mediterranean and the Atlantic side of Central America, i.e. the Caribbean Sea and the Gulf of Mexico. Thus the species could be called "circumtropical and -warm-temperate."

Summing up, the following grouping of the species can be recognized: 8 species, that is more than one-third, are cosmopolitan, amongst them the most abundant, Chromadora nudicapitata, and the third abundant, Eurystomina ornatum. To this group might be added Chromadora macrolaimoides.

7 species are Pacific, amongst them the second and fourth in abundance, Euchromadora Tokiokai and Spilophorella tollenifera, both new species.

The remaining 5 species have a distribution which in European-Asiatic waters is either subtropic-Mediterranean (group 2) or boreal-Arctic (group 3). None of these species is very abundant. 
Finally the compatibility of the geographical distribution of the present species with Exman's rule may be discussed. It should, however, be kept in mind that here more than ever all conclusions must be regarded as preliminary since they are built on incomplete data.

EKMAN (see e.g. 1953, p. 72) states that the pelagic and abyssal region between outermost Polynesia and America is a very efficient barrier for the east-west dispersal of marine littoral animals. "The further we go from the rich Indo-Malayan Archipelago the poorer the littoral fauna becomes....."....." When, proceeding further east, we reach the coast of America we meet there with a fauna which, although living in the same ocean, nevertheless shows a decidedly closer relationship to the Atlantic fauna."

In a strict sense only the Indo-West-Pacific and the American warm-water Pacific fauna should be compared. The present nematode collection contains 7 species, of which 3 are new, belonging to these two faunal elements. If we regard the new species as restricted to the West-Pacific there are three species (Viscosia carnleyensis, Paracanthonchus hawaiiensis and Euchromadora amokurae) which occur on both sides of the Pacific.

However, if we take into account the whole material there are many more species which occur on both the west and the east coast of the Pacific. Since this result is brought about by including the more or less cosmopolitan species we can, at the present state of our knowledge, not be sure whether the dispersal of these animals has taken place across the Pacific or across the Atlantic by means of flotsam, or along the coasts of Japan, the Kurile Islands and the Aleutian Islands to the west coast of North America. This latter route is very probable since all the widely spread nematodes must be regarded as eurythermal and should be able to stand the low temperatures which they encounter in the cold-temperate and arctic climate of the North Pacific. With the exception of the three Pacific species mentioned above the following species occur on both sides of the Pacific: Syringolaimus striaticaudatus, Oncholaimus dujardini, Halichoanolaimus robustus, Desmodora scaldensis, Chromadora nudicapitata, Chromadorella filiformis, Spilophorella paradoxa and Chromadoropsis parva. Doubtful is Eurystomina ornatum which has been reported from California by Allgen (1947, 1951), but the data do not seem to be very reliable.

Chromadora macrolaimoides has hitherto not been found on the east coast of the Pacific, but on the Atlantic side of Central America. Thus we see that from the collection of Japanese nematodes at my disposal 8 cosmopolitan and 3 Pacific species are known to occur on both sides of the Pacific, to which perhaps can be added a doubtful species and one which probably will also be found on the American Pacific coast. These are altogether 13 species, that is to say, about $62 \%$ of the total of 21 nematodes determined.

This certainly supports the idea of the general cosmopolitan occurrence of marine nematodes which I myself have criticized in a recent paper (1953). However, I might take this opportunity to stress the extreme difficulty of classifying marine nematodes. 
Although it seems to be fairly easy to determine nematodes from a well known area, the minute difference which might exist between closely related species from distant geographical regions are almost unkown. One certainly could not be proved wrong if one refused to accept any determination of marine nematodes from lesser know regions (that is to say, from all but the littoral of the North Atlantic and the Mediterranean) if they are not based on both males and females and accompanied by figures, or at least by absolute measurements and a succinct description. For example, in this paper I determined Paracanthonchus hawaiiensis, Halichoanolaimus robustus, Desmodora scaldensis, Chromadora brevipapillata, Euchromadora amokurae, Spilophorella paradoxa and Paramonhystera paranormandica, that is, onethird of all species, on the basis of females and (or) juveniles only, because I could not detect any differences between them and the typical species as known to me, or the original descriptions. It might be that there do not exist any noticeable differences in female, particularly not in juveniles, but that, nevertheless, the males would supply such small but distinct differences as would render necessary the establishment of separate species. I want to refer once again to the two species Enoplus communis and E. michaelseni which were admirably described by DE MAN in two papers (1886 and 1904). It is not possible to distinguish these two species on the basis of juveniles, whereas the males supply sufficient differential characters. If my doubts are true, this would very much upset all zoogeographical conclusions based on our present knowledge of the taxonomy of marine nematodes, including those touched in the present paper. Let us, for example, consider Altgen's paper on the nematode fauna of Hawaii (1951 part I). There are 53 species of which 23 were determined on the basis of females and juveniles, 9 on the basis of juveniles alone, together 32 species, or about $60 \%$ of the total of species found. If only a fraction of these $60 \%$ were wrongly classified this would give an entirely erroneous picture of the Hawaiian nematode fauna which would be perpetuated through the literature until correct and incorrect data became indistinguishable.

I do not advocate the suppression of all determinations based on females and juveniles (I myself do not follow this prudent advice), but I am convinced that, in order to render these determinations reliable, much more precise and painstaking methods of detecting and describing differential characters in nematodes have to be employed than has been (and is still) the case. Only by this means might we be able to assemble a number of incoherent and unreliable data into a system on which zoogeographical conclusions can be based.

To make a positive suggestion I consider it worth while undertaking an exact comparison between similar habitats of distant geographical regions in order to find out how great, or how small, is the similarity of the two nematode faunas. I hope to have contributed to this goal in my paper on the Chilean nematodes in which each species found was figured and described. 


\section{BIBLIOGRAPHY}

Allgen, C. 1933. Freilebende Nematoden aus dem Trondheimsfjord. Capita Zoologica, IV/2, pp. 1-162.

__ 1947. West American Marine Nematodes. Vidensk. Medd. Dansk naturh. Foren., 110, pp. $65-219$.

1951. Pacific Freeliving Marine Nematodes, Ib., 113, pp. 263-411.

BRUnett, B. 1951. Observazioni su alcune species del genere Euchromadora de Man 1886 (Nematoda-Chromadoridae). Monitore Zool. Italiano, 59, pp. 74-81.

Chitwood, B. G. 1951. North American Marine Nematodes. Texas JI. Sc., 3, 4, pp. 617-72.

Совв, N. A. 1920. One hundred new nemas. Contr. Sc. Nematology 9, Waverly Press, pp. 217-343.

Ditlevsen, H. 1921a. Marine freeliving Nematodes from the Auckland and Campbell Islands. Vidensk. Medd. Dansk naturh. Foren., 73, pp. 1-32.

1921 b. Nematological Notes. Ib., 74, pp. 57-67.

Eberth, C. J. 1863. Untersuchungen über Nematoden. Leipzig. 77 pp,

EkMAN, S. 1953. Zoogeography of the Sea. Sidgwick \& Jackson, London, 417 pp.

FILIPJEv, I. 1918. Svobodnochivuchtchija morskija Nematodi okrestnostej Sebastopolja. Trav. Lab. Zool. \& Stat. Biol. Sebastopol, Acad. Sci. Russ., 2, 4, pp. 1-614.

1922. Encore sur les Nématodes libres de la mer Noire. Acta Inst. agron. Stauropolitana, $1,16$.

KREIS, H. 1926. Weiterer Beitrag zur Kenntnis der freilebenden marinen Nematoden. Arch. Naturgesch., 92, Abt. A, 8, pp. 1-29.

DE MAN, J. 1886. Anatomische Untersuchungen über freilebende Nordseenematoden. Leipzig.

___ 1904. Resultats du Voyage du S. Y. Belgica. Exp. antarct. Belg. Zool. Nematodes libres. Anvers 1904.

Mrcoletzky, H. 1922. Neue freilebende Nematoden aus Suez. Sitz. Ber. Akad. Wiss. Wien, math-naturw. Kl., Abt. 1, 131, pp. 77-103.

___ 1924a. Weitere Beiträge zur Kenntnis freilebender Nematoden aus Suez. Ib., 132, pp. $225-62$.

1924 b. Letzter Bericht über freilebende Nematoden aus Suez. Ib., 133., pp. 137-79. \& KREIS, H. 1930. Freilebende marine Nematoden von den Sunda-Inseln. 1. Enoplidae. Vidensk. Medd. Dansk naturh. Foren., 87, pp. 243-339.

Stelner, G. 1915. Freilebende marine Nematoden von der Küste Sumatras. Zool. Jb. (Syst.), 38 , pp. 223-244.

1916. Freilebende Nematoden aus der Barentssee. Ib., 39, pp. 511-676.

1922. Ostasiatische marine Nematoden. Ib., 44, pp. 195-225.

\& HòpPli 1926. Studies on the Exoskeleton of some Japanese marine Nemas. Arch. Schiffs-Tropenhygiene, 30 , pp. 547-76.

Stekhoven, S. 1950. Mediterranean Freeliving Marine Nematodes I. The Bay of Villefranche. Mém. Mus. Roy. Hist. nat. Belg. Bruxelles, 2. ser., Fasc. 37, 1-220.

Wieser, W. 1953. Free-living Nematodes. I. Enoploidea. Chile Reports 10. Lunds Univ. Årsskrift, N. F. Avd. 2, 49, no. 6, pp. 1-155.

1954. Id., II. Chromadoroidea. Ib. (In the press).

1955. Id., III. Axonolaimoidea and Monhysteroidea. Ib. (In the press). 